\title{
Conservation Conferences and Expert Networks in the Short Twentieth Century
}

Citation for published version (APA):

de Bont, R., Schleper, S., \& Schouwenburg, H. (2017). Conservation Conferences and Expert Networks in the Short Twentieth Century. Environment and History, 23(4), 569-599.

https://doi.org/10.3197/096734017X15046905071889

Document status and date:

Published: 01/11/2017

DOI:

10.3197/096734017X15046905071889

Document Version:

Accepted author manuscript (Peer reviewed / editorial board version)

Document license:

CC BY-NC-ND

\section{Please check the document version of this publication:}

- A submitted manuscript is the version of the article upon submission and before peer-review. There can be important differences between the submitted version and the official published version of record.

People interested in the research are advised to contact the author for the final version of the publication, or visit the DOI to the publisher's website.

- The final author version and the galley proof are versions of the publication after peer review.

- The final published version features the final layout of the paper including the volume, issue and page numbers.

Link to publication

\footnotetext{
General rights rights.

- You may freely distribute the URL identifying the publication in the public portal. please follow below link for the End User Agreement:

www.umlib.nl/taverne-license

Take down policy

If you believe that this document breaches copyright please contact us at:

repository@maastrichtuniversity.nl

providing details and we will investigate your claim.
}

Copyright and moral rights for the publications made accessible in the public portal are retained by the authors and/or other copyright owners and it is a condition of accessing publications that users recognise and abide by the legal requirements associated with these

- Users may download and print one copy of any publication from the public portal for the purpose of private study or research.

- You may not further distribute the material or use it for any profit-making activity or commercial gain

If the publication is distributed under the terms of Article $25 \mathrm{fa}$ of the Dutch Copyright Act, indicated by the "Taverne" license above, 


\title{
Conservation Conferences and Expert Networks in the short Twentieth Century
}

\author{
Raf De Bont* \\ Simone Schleper** \\ Hans Schouwenburg*** \\ *Email: r.debont@maastrichtuniversity.nl \\ **Email: simone.schleper@maastrichtuniversity.nl \\ ***Email: h.schouwenburg@uu.nl
}

History Department

Universiteit Maastricht

Grote Gracht 90-92

6211 SZ Maastricht, The Netherlands

\begin{abstract}
The twentieth century witnessed the rise of a conservation movement that presented itself as 'international' and 'science-based'. This article analyses the changing transnational networks of experts mobilised by this movement. It does so by studying the participant lists of 21 influential international conservation conferences held between 1913 and 1990. On the basis of a database we were able to trace changes in the national background, disciplinary allegiance and gender balance of conference attendants. Furthermore, we singled out a socalled 'congress elite' of often returning participants, whose background we analyse more in depth. The overall composition of the congress network as well as that of its elite, we show, changed only through a slow and laborious process. This process accounts for both the continuity in the sensibilities of international conservation experts and the gradual changes in their approach.
\end{abstract}

\section{Keywords}

International conservation, conferences, networks 
The twentieth century has seen the rise of a global and scientifically inspired movement devoted to nature conservation. Despite a growing historiography about this movement, we only have a limited understanding of the composition and long-term development of its networks. This has to be partially explained by the conceptual frameworks that have dominated the historiography. Much of the existing literature is organized around either institutions, ${ }^{1}$ individuals, ${ }^{2}$ ideas ${ }^{3}$ or policy plans, ${ }^{4}$ but the cross- and inter-institutional networks that have actually disseminated ideas, driven policies, and connected individuals have received little systematic exploration. Even the most ambitious publications that address the history of global conservation in holistic terms have shied away from mapping the multi-faceted network of international conservation in any detail. ${ }^{5}$ In this article we want to make a step in that direction.

As a means to get access to the global conservation network, this article analyzes participant lists of international conferences at which 'conservation experts' came together. During the twentieth century the conservation movement unremittingly presented its approach as science-based, but the science involved took various forms. ${ }^{6}$ We therefore deliberately use

\footnotetext{
${ }^{1}$ Good examples include: Martin Holdgate, The Green Web: A Union for World Conservation (London: Earthscan, 1999); Stanley Johnson, UNEP - The First Fourty Years: A Narrative (UNON, 2012); Alexis Schwarzenbach, Saving the World's Wildlife: WWF - The First 50 Years (London: Profile Books, 2011); Anna-Katharina Wöbse, Weltnaturschutz: Umweltdiplomatie in Völkerbund und Vereinten Nationen, 1920-1950 (Frankfurt am Main: Campus Verlag, 2011).

${ }^{2}$ Within this genre, autobiographies and personal recollections play a crucial role. See e.g: Aldo Leopold, A Sand County Almanac, and Sketches Here and There (New York: Oxford University Press, 1949); Raymond F. Dasmann, Called by the Wild: The Autobiography of a Conservationist (Berkeley and Los Angeles: University of California Press, 2002); Luc Hoffmann and Jil Silberstein, Luc Hoffmann: L'homme qui s'obstine à preserver la terre (Paris: Phébus, 2010).

3 Such ideas include 'biodiversity' or 'sustainable development': David Takacs, The Idea of Biodiversity: Philosophies of Paradise (Baltimore: Johns Hopkins University Press, 1996); Iris Borowy, Defining Sustainable Development for Our Common Future: A History of the World Commission on Environment and Development (Brundtlandt Commission) (London: Routledge, 2014).

${ }^{4}$ E.g. John McCormick, "The Origins of the World Conservation Strategy," Environmental Review: ER 10 (1986), 177-187; Stephen Bocking, "Lier science et pratique: l'histoire du Programme de L'UNESCO sur l'homme et la biosphere," in: 60 ans d'histoire de l'UNESCO: Actes du colloque international, Paris, 16-18 novembre 2005 (Paris: UNESCO, 2007), 389-393.

5 Cf. John McCormick, Reclaiming Paradise: The Global Environmental Movement (Bloomington and Indianapolis: Indiana University Press, 1989); William M. Adams, Against Extinction: The Story of Conservation (London and New York: Earthscan, 2004).

${ }^{6}$ Robert Boardman traced back the scientific ambitions of the international conservation movement to the 1940 s. We argue elsewhere, however, that at least from the 1910s onward, claims of its scientificity were ubiquitous. Robert Boardman, International Organization and the Conservation of Nature (London: Macmillan, 1981) 47; Raf De Bont, "Borderless Nature: Experts and the Internationalization of Nature Protection, 1890-1940," in
} 
the vague (and somewhat anachronistic) term of 'conservation expert' to refer to those people with specialized knowledge deemed useful for the preservation or conservation of living nature. This umbrella term offers room to do justice to both the diversity of the group and the historical changes of its composition. ${ }^{7}$

There are several reasons for why conference participation provides an obvious starting point for mapping the cross-border network of conservation experts. Since the nineteenth century, international conferences have been key sites for community-building on a global scale for both the sciences and social movements. ${ }^{8}$ More in particular, conferences have been shown to provide crucial meeting points for fostering 'epistemic communities' - groups with shared normative and causal beliefs, notions of validity, and policy goals. ${ }^{9}$ They constitute sites where knowledge about the state of nature is exchanged, where the role of conservation experts is constructed, and where the research community is embodied. ${ }^{10}$

In this article we use international conferences to study the compositional diversity of the global conservation network, and the changes in this diversity over time. Particular attention is paid to the disciplinary background, nationality and gender of conference attendants. The global conservation movement has repeatedly claimed an aura of scientific objectivity,

\footnotetext{
Scientists Expertise as Performance: Between State and Society, 1860-1960 ed. Evert Peeters et al. (London: Pickering and Chatto, 2015) 49-65.

${ }^{7}$ Throughout the twentieth century, conservation itself has always been a contested term with shifting meanings and linked up with different projects. Given the present-day discussions over conservation biology, it seems that the discussions will not end any time soon. See e.g. Michael Soulé, 'What is Conservation Biology? A New Synthetic Discipline addresses the Dynamics and Problems of Perturbed Species, Communities, and Ecosystems', Bioscience 35 (1985), 727-734; Peter Kareiva and Michelle Marvier, 'What is Conservation Science?', Bioscience 62 (2012), 962-969.

${ }^{8}$ Wolf Feuerhahn and Pascale Rabault-Feuerhahn, "Présentation: Science à l'échelle internationale," in $L a$ Fabrique Internationale de la Science. Les Congrès Scientifiques de 1865 à 1945, ed. Wolf Feuerhahn and Pascale Rabault-Feuerhahn (Paris : CNRS Éditions 2010) 5-15 ; Chris Leonards and Nico Randeraad, "Transnational Experts in Social Reform, 1840-1880," International Review of Social History 55 (2010), 215-239; Davide Rodogno, Bernhard Struck and Jakob Vogel (eds.) Shaping the Transnational Sphere: Experts, Networks and Issues from the 1840s to the 1930s (London: Berghahn, 2015).

9 Peter Haas, "Introduction: Epistemic Communities and International Policy Coordination," International Organization 46 (1991), 1-35.

${ }^{10}$ Mario Diani, "Networks and Social Movements: A Research Program," in Social movements and Networks: Relational Approaches to Collective Action, ed. Mario Diani and Doug McAdam (Oxford: Oxford University press, 2003), 299-319.
} 
internationalism, and inclusiveness. In this article we provide a diachronic overview of how these claims translated into reality. Which scientific disciplines were actually represented at the conferences? How did the involvement of different nationalities change over time? And to which extent did women gain access to the conservation community? We, finally, deepen the analysis by singling out the core group of regular conference-goers - the so-called 'congress elite $^{11}$ - and explore what distinguishes them from the average participant.

The temporal focus of this article is Eric Hobsbawm's 'short twentieth century'. The starting point is 1913, when the Swiss Paul Sarasin organized the International World Conference for Nature Protection in Bern. Although not the first international conservation conference, it was the first to frame threatened nature as a global common, rather than an object of national or imperial concern. ${ }^{12}$ As an end point of our analysis, we take the expert meetings that prepared a convention on biodiversity for the 'Earth Summit' that took place in Rio in 1992 - a conference that, according to at least one historian, gave 'global environmental issues their highest profile ever'. ${ }^{13}$ We selected 21 influential conferences that focused on the conservation of living nature, and brought together the data of their participant lists (comprising more than 4000 names) in an Excel database. Apart from names, these lists mostly indicated the nationalities of the participants, their gender and professional background. When this information was missing, we were - in the great majority of cases - able to fill the gaps. Taken together, the data of the 21 conferences help to understand the major trends in the composition of the international conservation conference circuit. We interpret these data in the light of the existing secondary literature as well as the published reports and archival material produced by the involved institutions and individuals.

\footnotetext{
${ }^{11}$ We borrow the term from: Leonards and Randeraad, "Transnational Experts," 235.

12 See more in depth: Bernhard Gissibl, The Nature of German Imperialism. Conservation and the politics of Wildlife in colonial East Africa" (Oxford and New York: Berghahn forthcoming).

${ }^{13}$ Holdgate, The Green Web, 216.
} 


\section{Selection of conferences}

The conferences we selected all have nature conservation as their main goal, were expertoriented and international in design. Furthermore, both their participants and latter-day historians marked them as having set the agenda for global conservation. We particularly selected those conferences that were crucial in developing action plans, declarations, conventions and institutions, and which in this way steered the activities of conservationists on the ground.

\begin{tabular}{|c|c|c|c|}
\hline \multicolumn{4}{|c|}{ Selection of Conferences } \\
\hline $\mathbf{N}^{\circ}$ & Date & Place & Official name \\
\hline 1. & 1913 & Bern & Internationale Weltnaturschutzkonferenz \\
\hline 2. & 1923 & Paris & Premier congrès international pour la protection de la nature \\
\hline 3. & 1931 & Paris & Deuxième congrès international pour la protection de la nature \\
\hline 4. & 1933 & London & $\begin{array}{l}\text { International Conference for the protection of the fauna and flora of } \\
\text { Africa }\end{array}$ \\
\hline 5. & 1938 & London & $\begin{array}{l}\text { Second International Conference for the protection of the fauna and } \\
\text { flora of Africa }\end{array}$ \\
\hline 6. & 1947 & Brunnen & Conférence international pour la protection de la nature \\
\hline 7. & 1948 & Fontainebleau & $\begin{array}{l}\text { Foundational meeting of the International Union for the Protection of } \\
\text { Nature }\end{array}$ \\
\hline 8. & 1949 & Lake Success & International Technical Conference on the Protection of Nature \\
\hline 9. & 1953 & Bukavu & $\begin{array}{l}\text { Troisième conférence international pour la protection de la faune et } \\
\text { la flore de l'Afrique }\end{array}$ \\
\hline 10. & 1962 & Seattle & First world conference on national parks \\
\hline 11. & 1965 & Bangkok & $\begin{array}{l}\text { Conference on conservation of nature and natural resources in } \\
\text { tropical South East Asia }\end{array}$ \\
\hline 12. & 1968 & Paris & $\begin{array}{l}\text { Intergovernmental conference of experts on the scientific basis for } \\
\text { rational use and conservation of the resources of the biosphere }\end{array}$ \\
\hline 13. & $1971 \mathrm{a}$ & New York & $\begin{array}{l}\text { Meeting of the intergovernmental working group on conservation for } \\
\text { the United Nations Conference on the Human Environment } \\
\text { (UNCHE) }\end{array}$ \\
\hline 14. & $1971 b$ & Ramsar & $\begin{array}{l}\text { International conference on the conservation of wetlands and } \\
\text { waterfowl }\end{array}$ \\
\hline 15. & 1972 & Yellowstone & Second world congress on national parks and protected areas \\
\hline 16. & 1974 & Cocoyoc & $\begin{array}{l}\text { UNEP/ UNCTAD symposium on "Patterns of resource use, } \\
\text { environment and development strategies" }\end{array}$ \\
\hline 17. & 1976 & Bonn & $\begin{array}{l}\text { Meeting of experts to consider the draft convention on conservation } \\
\text { of migratory species of wild fauna }\end{array}$ \\
\hline 18. & 1982 & Bali & Third world congress on national parks \\
\hline 19. & 1983 & Minsk & First international biosphere reserve congress \\
\hline 20. & 1986 & Ottawa & $\begin{array}{l}\text { Conference on conservation and development: implementing the } \\
\text { World Conservation Strategy }\end{array}$ \\
\hline
\end{tabular}




\begin{tabular}{|l|l|l|l|}
\hline 21. & $\begin{array}{l}1988- \\
1990\end{array}$ & Geneva & $\begin{array}{l}\text { Three meetings of the ad hoc working group of experts on biological } \\
\text { diversity }^{14}\end{array}$ \\
\hline
\end{tabular}

The selected conferences were influential for different reasons. Some - like the congresses held in Bern in 1913, or in Paris in 1923 and 1931 - were instrumental in defining the field of global conservation. Others were crucial for institution-building, such as the conferences in Brunnen (1947) and Fontainebleau (1948) that lay the foundation of the International Union for the Protection of Nature (IUPN). Still other conferences were significant for launching new approaches in conservation policy. The technical meeting in Lake Success (1949) and the Paris Biosphere Conference (1968) stressed the importance of conservation for natural resource management. The conference in New York (1971) served as the main preparatory meeting of conservation experts for the United Nations Conference of the Human Environment (UNCHE) in which conservation was to be explicitly linked to development. This link with development

\footnotetext{
${ }^{14}$ Recueil des procès-verbaux de la conférence internationale pour la protection de la nature: Berne, 17-19 novembre 1913 (Bern: s.n., 1913); Raoul de Clermont et al. eds., Premier Congrès international pour la protection de la nature (Paris: Société nationale de protection de la nature et d'acclimatation 1925); Abel Gruvel et al. eds., Deuxième congrès international pour la protection de la nature (Paris, 30 juin - 4 juillet 1931) (Paris: Société d'éditions géographiques, maritimes et coloniales, 1932); International conference for the protection of the fauna and flora of Africa. 1933. Typoscript; Second international conference for the protection of the fauna and flora of Africa. 1938. Typoscript; Johann Buttiköfer ed. Conférence internationale pour la protection de la nature (Brunnen, 28 juin - 3 juillet 1947) (Basel: Union provisoire pour la protection de la nature, 1947); International Union for the Protection of Nature, established at Fontainebleau, 5 October 1948 (Brussels: IUPN, 1948); International Technical Conference on the Protection of Nature, Lake Success, 22-29-VIII 194 (Paris and Brussels: UNESCO, 1950); Comptes rendus de la troisième Conférence internationale pour la protection de la faune et de la flore en Afrique, Bukavu, 26-31 octobre 1953(Brussels: CCTA, 1953); Alexander B. Adams, ed. First World Conference on National Parks: Seattle, Washington, June 30-July 7, 1962 (Washington: National Park Service, 1964); Lee M. Talbot and Martha H. Talbot eds. Conservation in Tropical South East Asia (Morges: IUCN, 1968). Intergovernmental Conference of Experts on the Scientific Basis for Rational Use and Conservation of the Resources of the Biosphere, Unesco House, Paris, 4-13 September 1968: (Paris: UNESCO, 1968); Erik Carp ed., International Conference on the Conservation of Wetlands and Waterfowl: Proceedings, Ramsar, Iran, 30 January - 3 February 1971 (Slimbridge: International Wildfowl Research Bureau, 1972); "Report of the Intergovernmental Working Group on Conservation on Its First Session New York, 14-17 September 1971 A/CONF.48/IWGC.I/11.” Typoscript, New York, 1971; Hugh Elliott ed. Second World Conference on National Parks: Yellowstone and Grand Teton National Parks, U.S.A., September 18-27, 1972 (Morges: IUCN, 1974); "The Declaration of Cocoyoc," World Development, 3 (1975), 141-148; Draft Convention on Conservation of Migratory Species of Wild Fauna: Summary Record of Meeting of Experts (Bonn: IUCN, 1976); National Parks, Conservation and Development: The Role of Protected Areas in Sustaining Society (Washington: Smithsonian Institution Press, 1984); Conservation, Science and Society contribution to the first International Biosphere Reserve Congress, Minsk, Byelorussia, USSR, 26 September-2 October 1983 (Paris: UNESCO, 1984); Conservation with Equity: Strategies for Sustainable Development (Gland: IUCN, 1987); UNEP, "Report of the Ad Hoc Working Group on the Work of its First, Second and Third Section," (UNEP/Bio.Div.1/3, 9 November 1989) 8-15; (UNEP.Bio.Div.2/3, 23 February 1990) Annex 2, 1-19; (UNEP.Bio.Div.3/Inf.7, 13 Augustus 1990) 2-30, Dag Hammarskjöld Library, New York.
} 
would be further worked out at the conferences of Cocoyoc (1974), Minsk (1983) and Ottowa (1986), while the three meetings in Geneva (1988-1990) were instrumental in promoting the concept of 'biodiversity'. Furthermore, we also selected conferences that were significant in creating and sustaining networks around specific conservationist themes. Three subsequent conferences, held respectively in Seattle (1962), Yellowstone (1972) and Bali (1982), brought together a great number of conservationists around the theme of national parks. The Ramsar conference in 1971 heightened the sensibility for wetlands, whereas the Bonn meeting in 1976 gathered experts around the issue of migratory species. Finally, at several influential conferences the attention of the global conservation community concentrated on particular regions. Africa, for instance, was the particular object of meetings in London (1933 and 1938) and Bukavu (1953), whereas South-East-Asia was the focus of the Bangkok conference in 1965.

Overall, we attempted to have a relatively even representation of conferences over time. Nonetheless, the increasing number of international conferences devoted to conservation is also reflected in our selection - resulting in a stronger representation of the later decades. Furthermore, some periods in time (such as the late 1940s and the years around 1970) clustered international conservation activities and are therefore more visible in the database. Apart from the temporal spread, diversity, size and dynamics also played a role in the selection. The selected conferences range from small technical meetings of experts that were set up to prepare international conventions, to large-scale gatherings of hundreds of people at which the conservation community discussed common goals and voiced their concerns. Both, we believe, were decisive in globalizing the issue of nature conservation and giving it a scientific aura.

Historians have pointed at the important role transnational expert groups have played since the beginning of the twentieth century in 'creating' global concern around particular 
environmental topics. ${ }^{15}$ The rhetoric of transnational experts, in which both their own research interests and organizational networks were indicated as 'global', should of course not be taken at face value. These categories were strategical, and especially in the early twentieth century they were used to further the interests of a small group of European actors. It is important to see that, alongside these actors, other conservationists were engaged in alternative forms of international cooperation. In the early twentieth century, North American conservationists, for instance, tried to set up nature preservation in Latin America through 'Pan American' meetings and institutions. Similarly they attempted to gain influence in East Asia and Oceania by putting conservation on the agenda of the Pan-Pacific Science Congresses. ${ }^{16}$ Conferences organized as part of these alternative (more regionally defined) 'internationalisms' have not been taken up in the database. Their existence, however, needs to be acknowledged in order to properly situate the ones that have been selected.

\section{The Power of Place}

When explaining his ambitions at the Bern conference of 1913, Paul Sarasin stressed his goal to set up a commission for Weltnaturschutz ('global nature protection'). ${ }^{17}$ As indicated, this does not mean that the networks created at conferences such as the one in Bern evenly represented the different regions from the world. Rather the opposite is the case. Until the late 1940s, the selected conferences brought together a group that was dominated by a small number of western European countries. France, the United Kingdom, Belgium, Switzerland and the Netherlands account for $78 \%$ of the participants present at the first seven conferences in the

\footnotetext{
15 Madeleine Herren, "Between Territoriality, Performance, and Transcultural Entanglement (1920-1939): A Typology of Transboundary Lives," Comparativ: Zeitschrift für Globalgeschichte und Vergeleichende Gesellschaftsforschung, 6 (2013) 117.

${ }^{16}$ See: Mark V. Barrow Jr., Nature's Ghosts: Confronting Extinction from the Age of Jefferson to the Age of Ecology (Chicago and London: The University of Chicago Press, 2009) 168-200; Tomoko Akami, "Beyond Empires' Science: Inter-Imperial Pacific Science Networks in the 1920s," Networking the International System : Global Histories of International Organizations, ed. Madeleine Herren (Dordrecht : Springer, 2014) 123.

${ }^{17}$ Paul Sarasin, Ueber die Aufgaben des Weltnaturschutzes. Denkschrift gelesen an der Delegiertenversammlung zur Weltnaturschutzkommission (Basel: Verlag von Helbing \& Lichtenbahn, 1914).
} 
database. ${ }^{18}$ In practice, the conservation network was organized around a few well-connected cities: Paris, London, Brussels, Amsterdam, Geneva and Bern. Conservationists from these centers met regularly and the key institutions of international conservation developed in this limited geographical area. Paris had the Muséum d'histoire naturelle, and, since 1945, the headquarters of the United Nations Educational, Scientific and Cultural Organization (UNESCO). Brussels housed the International Office for the Protection of Nature (IOPN, founded in 1928) and, from 1948 onward, the IUPN. The Society for the Preservation of the Fauna of the Empire (SPFE) and the British Museum were accommodated in London. The fact that, with the exception of the Swiss, the core group of the international network represented colonial countries (and were tied to colonial circles) is significant as well. Its members might have met in a few modern metropolises, but their interests largely concerned distant tropical places in the colony. ${ }^{19}$

The European dominance in the period up until the 1950s has partially to do with the available transport technologies. Travel by train was customary for conference participants in the interwar years. Steamship connections became an option for transatlantic travel since they dropped their prices in the 1920 s, but they still required a journey of more than a week. ${ }^{20}$ Leading figures of the conservation network (such as Jean-Paul Harroy) started to use air travel in the 1940s, but cheaper steamships were still common for most transatlantic conferencegoers. ${ }^{21}$ The American delegation to Fontainebleau for instance came by ship. ${ }^{22}$ This explains why, despite their global ambitions, the European core group, for a long time, kept organizing

\footnotetext{
${ }^{18}$ And even when participants of the organizing countries are excluded, these five countries still represent $47 \%$ of the attendants.

${ }^{19}$ See also: Anna-Katharina Wöbse, “"The World After All was One': The International Environmental Network of UNESCO and IUPN, 1945-1950,"' Contemporary European History 20 (2011), 331-348; De Bont, "Borderless Nature".

${ }^{20}$ When, in 1930, the leading European conservationist Pieter-Gerbrand van Tienhoven travelled to the United States in order to meet up with kindred spirits, his boat trip from Amsterdam to New York took him 10 days. He made such a trip only once during his lifetime. Tienhoven to Harold Coolidge, 13 November 1930, Tienhoven Papers, Amsterdam City Archive (ACA), 1283-160.

${ }^{21}$ Eleen Sam to Charles Bernard, 18 July 1949, 18 July 1949, UNESCO Archives, Paris, 502.7 A 01 IUCNNR-6.

${ }^{22}$ Sam to Max Nicholson, 11 August 1948, UNESCO Archives, Paris, 502.7 A 01 IUCNNR-6.
} 
their conferences in northwestern Europe. The suggestion that IUPN could be founded in the United States, for instance, was quickly brushed aside out of fear that the Europeans would be insufficiently represented. ${ }^{23}$

In 1949, the first major global conservation conference was held outside Europe, in Lake Success. This was indicative of a shift in the composition of the network. ${ }^{24}$ Before, the United States only sent few delegates to the selected conservation meetings; post-1949, they quickly became the dominant group. Of course, this development did not materialize from thin air. Many of the Americans who took up a leading role in the postwar circuit had already established ties with the European network in the 1920s and 1930s, or had been active in the Pan-American and Pan-Pacific conferences. ${ }^{25}$ Yet, it was only in the late 1940s that they took a coordinating role on the global scene. Making up more than $16 \%$ of the total number of participants of the selected postwar conferences, the Americans easily outrank other nationalities. This shift also had institutional consequences. As compared to the Europeans, Americans could rely on strongly developed state agencies for the environment as the National Park Service and the Fish \& Wildlife Service. Furthermore, they had access to philanthropic money - which the Europeans actively tried to integrate in the network. ${ }^{26}$ Alongside the affluent Americans, also Canadian and Australian representatives became more numerous at the international conservation stage. Several of them also took up leading roles, particularly since the 1970 s (with Maurice Strong from Canada, and Frank Nicholls from Australia as striking examples). ${ }^{27}$ On the European side, the United Kingdom and France remained well-represented. Making up respectively 5 and $4,5 \%$ of the participants at postwar conferences, they come far behind the

\footnotetext{
${ }^{23}$ Bernard to George E. Brewer, 9 March 1948, UNESCO Archives, Paris, 502.7 A 01 IUCNNR-6.

${ }^{24}$ Compare: Adams, Against Extinction, 50.

25 The main American leaders of global conservation in the postwar years - such as Henry Fairfield Osborn Jr, Harold Coolidge and Alexander Wetmore - can serve as ilustration.

26 This hope is amongst others expressed in: Jan Westermann, 'International Technical Conference on the Protection of Nature', 1949, Tienhoven Papers, City Archive, Amsterdam, 1283-228

${ }^{27}$ The Australians and Canadians made up respectively 3,5\% and 6,5\% of the delegates at the conferences of the 1970 s and 1980s.
} 
Americans, but still rank second and third. Particularly the British experts remained highly influential - with their Nature Conservancy serving as a reference point for global conservation. $^{28}$

Geopolitics was clearly important for the dynamics of the conferences. It explains, for instance, the limited overall presence of German conservationists. While the Germans were considered a leading voice with regard to nature protection before World War I, they lost this position after 1918. Germans were uninvited at the Paris conference of 1923, and had problems re-entering the community after. ${ }^{29}$ The fact they had lost their colonies (the focus of much global conservation interest) did not help, nor did the rise of Nazism. World War II implied another backlash, particularly because the headquarters of international organizations and NGOs were monopolized by former Allied forces. ${ }^{30}$ Throughout the late 1940s Germans remained absent at the major conservation conferences. Wolfgang Burhenne - a former resistance member - was the first German to return to the international circuit, attending the IUPN General Assembly of 1950 in Brussels. ${ }^{31}$ The inclusion of other German participants was somewhat sensitive, but a small delegation was nonetheless sent to the IUPN General Assembly of $1952 .^{32}$ In the following years, German presence on the international scene gradually increased, but without catching up with the traditionally strong British and French delegations.

The Cold War left its traces too. Overall, communist countries were strongly underrepresented at the selected conferences. Pre-war contacts with Polish scientists such as

\footnotetext{
${ }^{28}$ E.g. in What is Nature Protection? (Brussels: IUPN, 1952) 4.

${ }^{29}$ Although nature protection was presented as a 'universal question' at the Paris conference, attendants were also addressed as representatives of the 'allied countries and friends'. See Jean Delacour's speech: De Clermont et al. eds., Premier Congrès 31; De Bont, “ Borderless Nature”.

${ }^{30}$ Next to the aforementioned seats of UNESCO in Paris and IUPN in Brussels, we could refer to the United Nations headquarters in New York and the International Council for Science, also in Paris.

${ }^{31}$ Proceedings and Reports of the Second Session of the General Assembly held in Brussels, 18 to 23 October 1950 (Brussels: IUPN, 1951) 8.

${ }^{32}$ At a technical meeting of IUPN in 1951 in The Hague, a German representative (count Dönhoff) was still held off in order 'to avoid incidents'. The year after, at the General Assembly in Caracas, the German delegation consisted of four members including Hans Klose - the leader of the Reichstelle für Naturschutz before 1945 and the Zentralstelle für Naturschutz und Landschaftspflege after 1945. Charles Bernard to Roger Heim, September 21, 1951, Roger Heim Papers, Folder 48, Muséum d'Histoire Naturelle, Paris; Proceedings and Reports of the the Third General Assembly held in Caracas (Venezuela), 3 to 9 September 1950 (Brussels: IUPN, 1952) 5.
} 
Walery Goetel continued after 1945, but this hardly led to an even representation of the two ideological blocs. Soviet representatives were absent at the big conservation congresses in the first decade after WWII (with the exception of one diplomat at Lake Success). Only after the death of Stalin contacts were gradually established and small delegations from the Ministry of Agriculture and the Academy of Sciences were sent to the general assemblies of the International Union for the Conservation of Nature (IUCN, the new name of the former IUPN). ${ }^{33}$ Yet, the contacts remained infrequent, despite several attempts of the conservation community to reach out via the non-governmental IUCN. In the 1950s UNESCO-officials explicitly indicated that, as an NGO, IUCN was permitted to have 'sheep and goats mingle for the common good'. ${ }^{34}$ Most conservationists of the international circuit strove for a nonideological aura, and IUCN exemplified this ambition. Until well into the 1960s, for instance, both East and West Germans were listed in conference proceedings under the common heading 'Germany' - which was seen as an expression of a 'proper non-political attitude'. ${ }^{35}$ At the same time it was stressed that environmental problems occurred on both sides of the Iron Curtain and needed a global expert-based response. ${ }^{36}$ In practice, however, the international conservation circuit remained dominated by western experts.

This continued domination of the west can partially be explained by traditional prewar ties as well as by practical problems in crossing the Iron Curtain. ${ }^{37}$ In meetings with an intergovernmental setup, political manoeuvring further complicated collaboration. When the

\footnotetext{
${ }^{33}$ Proceedings and Papers of the Fourth General Assembly held at Copenhagen, 25 August to 3 September 1954 (Brussels: IUPN, 1955) 12; Fifth General Assembly. Edinburgh: 20-28.6.1956: Proceedings (Brussels: IUCN, 1957) 27. See also: Douglas R. Weiner, A Little Corner of Freedom: Russian Nature Protection from Stalin to Gorbachëv (Berkeley: University of California Press, 1999) 142-143 and 196.

${ }^{34}$ C.M. Berkeley to Tracy Philips, March 16, 1956, UNESCO Archives, 502.7 A 01 IUCNNR -6.

${ }^{35}$ Philips to Berkeley, February 8, 1956, UNESCO Archives, 502.7 A 01 IUCNNR -6.

${ }^{36}$ See e.g. Edward Graham, 'Poland host to International Union for the Conservation of Nature', offprint from American Forests, Sept. 1960502.7 A 01 IUCNNR -6.

${ }^{37}$ The latter is clearly illustrated by the International Biological Program - another expert-based non-governmental project. Within the Conservation section, Andrei Bannikov of the USSR was to be reached through Anna Medwecka-Kornas of Poland. Medwecka-Kornas, however, had returning difficulties herself attending meetings because of visa issues. Max Nicholson to Gerardo Budowski, 16 Jan. 1969, Royal Society Archives, SCIBP papers, NHM Box1, Folder: First GA SCIBP 1964, and Medwecka-Kornas to Nicholson 16 May 1967, Royal Geographical Society, Max Nicholson papers, Box 4.
} 
German Democratic Republic was excluded from participation at UNCHE (1972), communist governments boycotted the meeting. ${ }^{38}$ Again it took time for interaction to resume. After the organization of a UNESCO conference on environmental education in Tbilisi (1977), particularly the International Biosphere Reserve Congress in Minsk (1983) showed the renewed willingness on both sides of the Iron Curtain to include the USSR in the global conservation network. ${ }^{39}$ In those years, some Soviet scientists (such as Vladimir Sokolov) managed to play a more prominent international role, but, partially because of returning incidents, their overall number remained limited. ${ }^{40}$ With regard to communist China, finally, the situation was even more distinct. Chinese representatives were largely absent during the entire period studied. Apart from two single delegates in respectively Paris (1968) and Bonn (1976), the Chinese only sent representatives from the 1980s onward - and also then only in limited numbers.

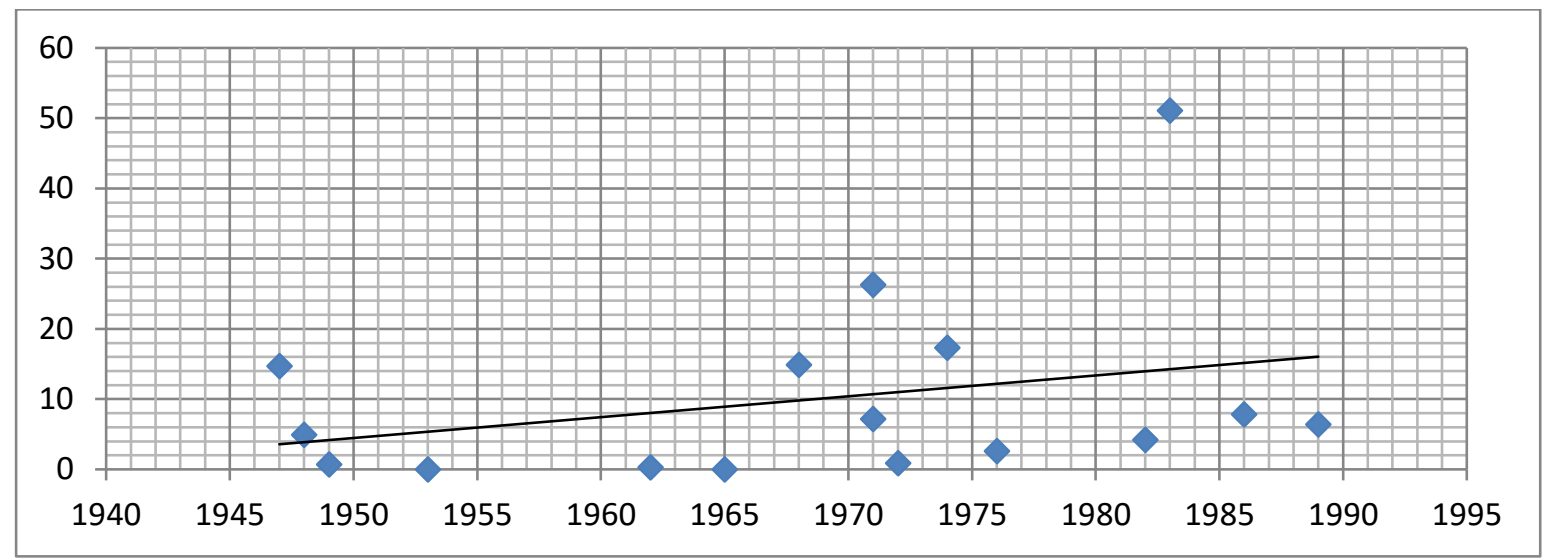

Overall representation of participants from communist countries at the selected conferences between 1945 and 1990, in percentages. The obvious outlier is the Biosphere Reserve Congress in Minsk (1983).

\footnotetext{
${ }^{38}$ Kai Hünemörder, Die Frügeschichte der globale Umweltkrise und die Formierung der deutschen Umweltpolitik (1950-1973) (Stuttgart: Franz Steiner Verlag, 2004), 262-267.

${ }^{39}$ It should be mentioned however that this time USSR experts were highly overrepresented because a boycott of the Russian airline Aeroflot by the members of the North Atlantic Treaty Organization (NATO) prevented most western representatives from attending. Michel Batisse to Bernd von Droste, Memo on Attendence at Minsk Congress as of 20 September 1983 (20 September 1983), UNESCO Archives: SC/ECO/562/47.10, box 460. See also: Phillip R. Pryde, Environmental Management in the Soviet Union (Cambridge: Cambridge University Press, 1991), 266-277.

${ }^{40}$ Dimitriy S. Pavlov and Vladmir S. Shishkin, “ Vladimir E. Sokolov: 1928-1998,” Oryx 32 (1998), 249.
} 
The relative representation of nationalities at conferences was of consequence. The fact that colonial networks of a particular number of European countries were dominant in the interwar years proved decisive for the geographical orientation of international conservation for decades to come. Groups concerned with aesthetic cultural landscapes in Europe had a far less defining influence on the international conference circuit than those interested in 'pristine' nature in the colony. ${ }^{41}$ This was further confirmed in the 1950s through influx of American conservationists, who had always particularly cherished the wilderness ideal. As we will see, it was also particularly through sciences that institutionalized in the Anglo-American world (such as ecology and wildlife management) that conservation in 'wild' tropical places would be conceptualized. ${ }^{42}$

\section{The Global South}

Before decolonization it was mostly European administrators or scientists with expeditionary experience, who took on the role of experts of the tropical 'wilderness' at international conferences. After World War II there was a growing sense that non-western representatives should be included in the network, but this idea was certainly not immediately reflected in the actual participation to conferences. The 1953 Conference for the Protection of Fauna and Flora in Bukavu offers a case in point. Most people present there were Europeans - the only exceptions being South-Africans, who, not surprisingly given the Apartheid regime, were all white.

\footnotetext{
${ }^{41}$ This has not only to do with the overrepresentation of colonial empires, but also with a division of labour in those empires. From Britain, for instance, he National Trust for Places of Historic Interest or Natural Beauty mostly remained absent from the international conservation conferences, whereas the Society for the Preservation of the Fauna of the Empire was systematically represented.

${ }^{42}$ Wiliam Cronon, William "The Trouble with Wilderness: Or Getting Back to the Wrong Nature," Environmental History, 1 (1996) 7-28; Michael Lewis, "Wilderness and Conservation Science," American Wilderness: A New History, Michael Lewis ed. (Oxford: Oxford University Press, 2007) 205-261.
} 


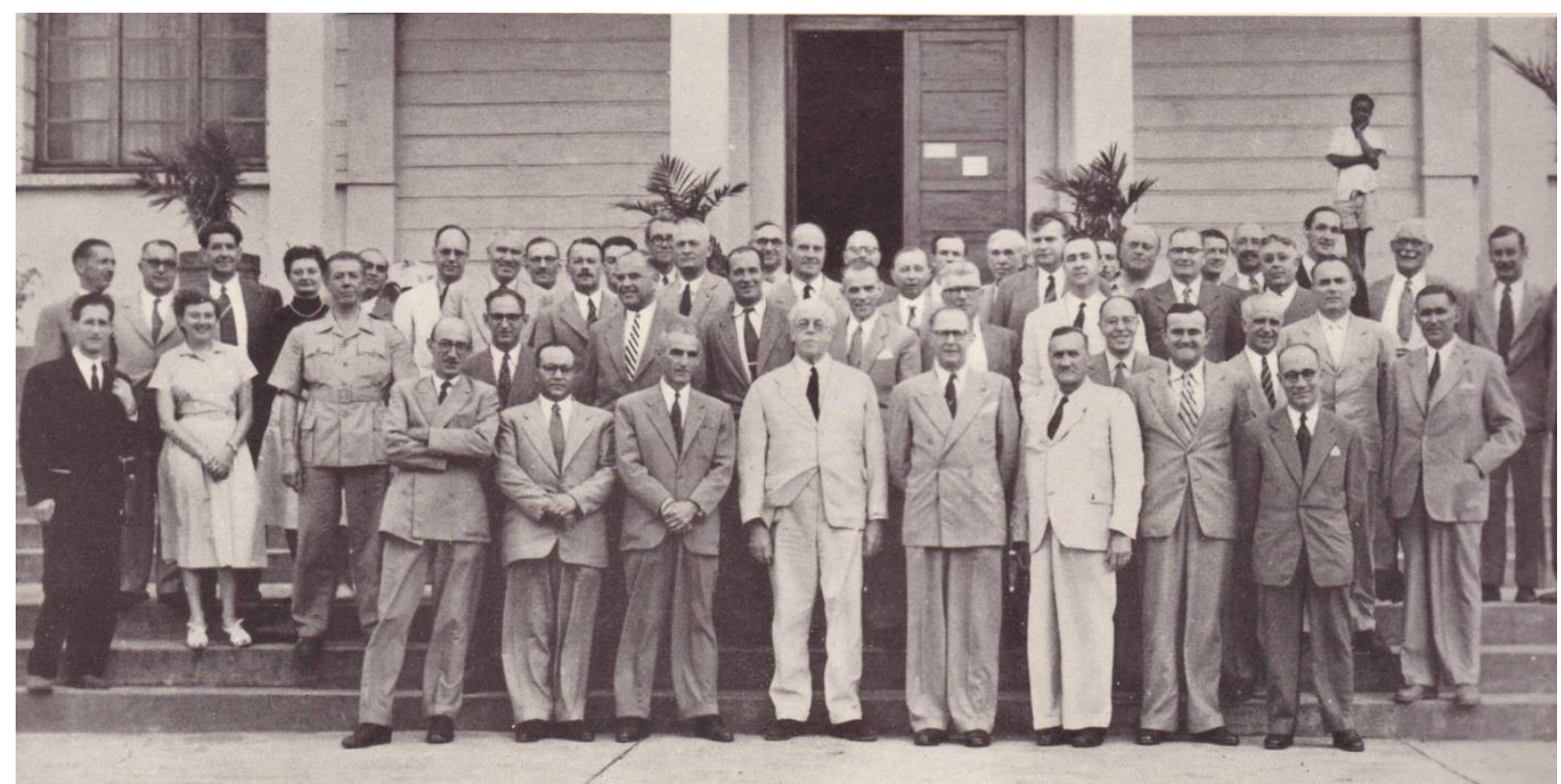

White men in suits. Although dealing with African fauna and flora, the international expert meeting at Bukavu (1953) was an exclusively white (and mostly European) affair.

Around 1960 western conservationists changed strategies. The imminent decolonization of Sub-Saharan Africa triggered fear that colonial conservation measures would soon be undone. As a counter-measure, conservationists believed international organizations should fill the gap that colonial administrations left behind, which was only deemed possible by getting in contact with new elites and local experts. In order to establish such contact, international conferences were increasingly held outside the western world. A good example is the Arusha Conference (of which, unfortunately, no complete participant lists remain), which was held when Tanganyika was on the verge of independence. The Bangkok Conference in 1965, then, repeated the trick for South-East Asia. ${ }^{43}$ Both were clear successes in mobilizing conservationists of the wider region. From around 1970, then, 'developing countries' also increasingly started sending delegates to international conservation conferences held outside their immediate vicinity, and their overall numbers gradually increased to more or less $50 \%$ of

\footnotetext{
${ }^{43}$ In a letter to Julian Huxley, for instance, Harold Coolidge stressed the importance of international conservation pressure 'so that newly developing countries would not get rid of [national parks] [...] as parts of their colonial past'. Coolidge to Huxley, 11 June 1960, Julian Huxley papers, Rice University, Houston. For the wider context see: Roderick Neumann, "The Postwar Conservation Boom in Colonial Africa," Environmental History 7 (2002), 37-39; Schwarzenbach, Saving the World's Wildlife, 43-46.
} 
the delegates by 1990. Such inclusion was actively sought by the leaders of the conservation organizations themselves. ${ }^{44}$ While in the 1960 s fears about the fate of colonial park infrastructure were crucial as a motivation, in the 1970s it was the Environmental Revolution, a global concern with development in the 'Third World', and the increasing importance of the United Nations (UN) in environmental matters that proved major stimuli. In this context, incorporating non-western experts could help to ward off mounting criticism of conservation's eurocentrism as well as foster credibility with the UN and newly established environmental ministries in the Global South. ${ }^{45}$

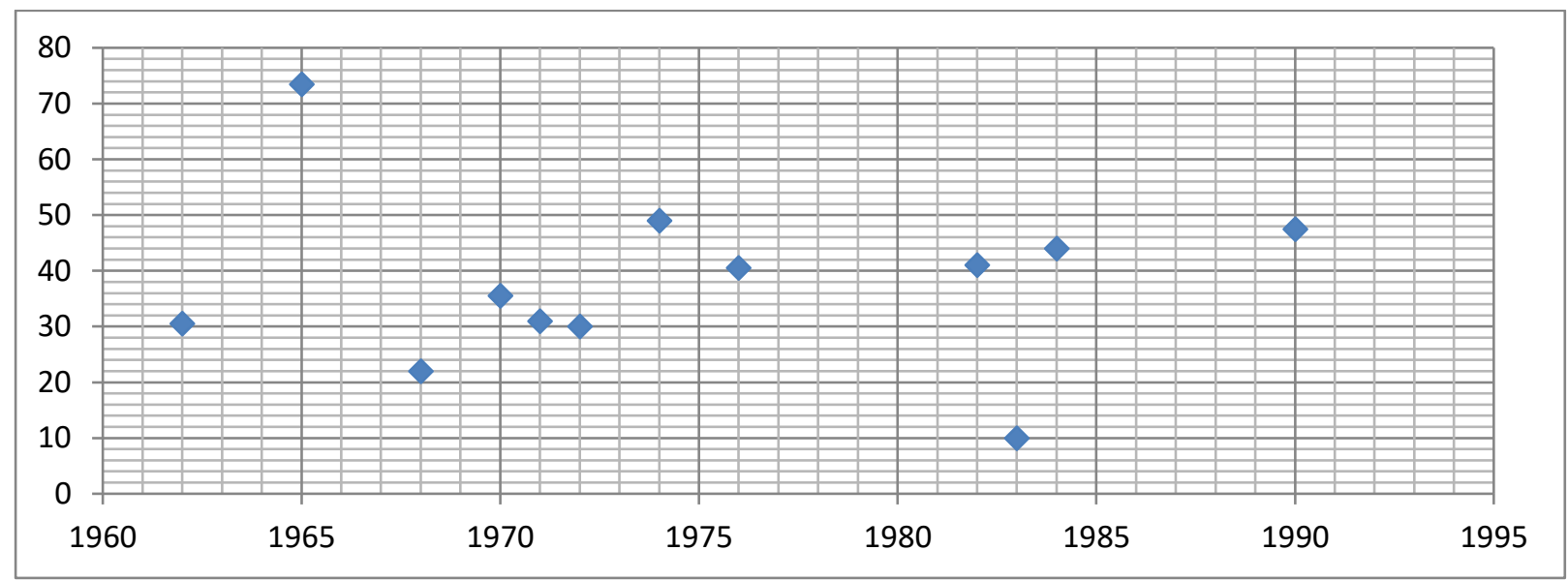

Relative presence of the 'developing countries' at international conservation Conferences from 1960 to 1990 in percentage. The term 'developing countries' refers here to representatives of Latin America, Africa, and Asia with the exclusion of the USSR and Japan. The outliers are the conferences of Bangkok (1965) and Minsk (1983) with respectively high and low representations of developing countries.

When looking at the participants of 'developing countries' that were drawn in the global network in more detail, it becomes clear that some countries were far better represented than others. Already in the 1960s some regional centers arose. In Latin America, the best represented

\footnotetext{
${ }^{44}$ Correspondence of IUCN-members shows that, by the 1970s, including scientists from 'Third World Nations' in the organisation's commissions was explicitly striven for, but also that it was seen as a relatively difficult task. See e.g. John Perry to Peter Scott, December 12, 1975, Richard Fitter papers: IUCN SSC, Weston Library, Oxford University.

${ }^{45}$ On this context: Stephen Macekura, Of Limits and Growth: The Rise of Global Sustainable Development in the Twentieth Century (Cambridge: Cambridge University Press, 2015) 96-99, 221 and 228-229.
} 
country in the database is Brazil, in Africa Kenya stands out, while in Asia India is particularly important.

The road to the global conservation network was different for the various countries concerned. In Brazil, home-grown experts and a well-established national conservation organization proved crucial. The Brazilian Foundation of the Conservation of Nature (FBCN) founded in 1958 was the first of its kind in Latin America. Its members had a scientific outlook and maintained good relations with the technocratic military government that took power in the 1960s. Their organization was modeled after the IUCN, and its leaders - Jose Candido de Melo Carvalo, Paulo Noguera-Neto, Maria Theresa Padua - easily found their way to the international conference circuit. At the same time, these experts also defended the development goals of the Brazilian government that, by the 1970s, aimed at a leadership role in international discussions on conservation in defense of the 'Third World'. ${ }^{46}$

In India the dynamics were somewhat different. In an early phase after independence, a strong interaction existed between local naturalist organizations such as the Bombay Natural History Society (BNHS) and U.S. ecologists connected to the Smithsonian Institution. By the 1970s, however, a nationalist and anti-imperialist agenda led the Indian government to monopolize the conservation agenda. This shift was not only discernible on the national level, but also found a clear reflection in the network present at international conferences. Like Brazil, India took a more assertive stance internationally, referring to poverty as the most important global environmental problem and presenting itself as a leader of the developing countries. In those years representatives of the old Smithsonian-BNHS network were replaced by government officials such as M.K. Ratsjisinh and Nalni Dhar Jayal. ${ }^{47}$

\footnotetext{
${ }^{46}$ Kathryn Hochstetter and Margaret E. Keck, Greening Brazil: Environmental Activism in State and Society (Durham: Duke University Press: 2007), 67-69; José Luiz de Andrade Franco and José Augusto Drummond, "Nature Protection: the FBCN and Conservation Initiatives in Brazil, 1958-1992," Historia Ambiental Latinoamericana y Caribeña 2 (2013), 338-367.

${ }^{47}$ Michael Lewis, Inventing Global Ecology: Tracking the Biodiversity Ideal in India, 1947-1997 (Athens: Ohio University Press, 2004).
} 
Kenya, finally, with its charismatic megafauna, had been an international conservation focal point since colonial times. In the 1950s, it became the object of what historians describe as a 'second scramble for Africa', which involved the growing control of international organizations over national park management. ${ }^{48}$ By 1960 this was followed by an active strategy by conservationists of winning over the new African leaders, and training local experts through organizations such as the African Wildlife Leadership Foundation in Washington. Kenyans like Perez Olindo and Walter Lusigi traveled to the United States to get degrees in range ecology and wildlife management. They returned to Kenya to become leaders of the national conservation movement, and maintained their transnational contacts through the conference circuit. ${ }^{49}$ It would be a mistake, however, to reduce Kenyan involvement in international conservation to cultural imperialism brought about by a transnational network. Local agency proved equally important. This agency was substantially strengthened when, in 1972, Kenya secured the headquarters of the newly-founded United Nations Environment Program (UNEP) for Nairobi. It did so mostly on the basis of 'Third World rhetoric' and by obtaining the support of non-aligned countries such as India. ${ }^{50}$ All the same, Kenyan UNEPofficials, such as the international conference regular Reuben Olembo, also received their scientific training in the United States.

The relatively strong presence of Brazilians, Indians and Kenyans at international conservation conferences should partially be explained by idiosyncratic interactions between global and national dynamics. Nevertheless, it is clear that all three countries offered the international network iconic instances of the 'pristine nature' that strongly resonated in the western media (the Amazonian rainforest, the tiger or the migrating herds of East-Africa).

\footnotetext{
${ }^{48}$ Neumann, "The Postwar Conservation Boom," 37-39.

${ }^{49}$ They studied respectively at Michigan State University and Colorado State University. On the African Wildlife Leadership Foundation and Olindo, see: J. Brooks Flippen, A Conservative Conservationist: Russell E. Train and the Emergence of American Environmentalism (Balton Rouge: Louisiana State University Press, 2006) 40-41. ${ }^{50}$ Johnson, UNEP, 28-36.
} 
When we include other 'developing countries' well-represented in the database (Venezuela, Indonesia, the Philippines, Thailand), we see how they map relatively well onto the threatened regions present-day conservationists describe as 'biodiversity hotspots' ${ }^{51}$ As we will see, it is the same species-rich tropical regions that have been preferred destinations of expeditions of the international conservation elite throughout the short twentieth century.

Finally, it should be noted that, for the period studied, the attendees of non-western nations were mostly metropolitan scientists or government officials, not representatives of the indigenous people living close to (or in) the mentioned biodiversity hotspots. To be true, from the 1980s onward indigenous people were increasingly seen as stakeholders in conservation matters - and their so-called 'traditional ecological knowledge' was starting to be recognized. They would, however, only slowly enter the conference circuit in the early $1990 \mathrm{~s} .{ }^{52}$ Even then, as geographer Stan Stevens has indicated, their presence remained relatively marginal and would be often more evident outside than inside the conference halls. ${ }^{53}$

\section{Types of Expertise}

All the conferences in our database presented conservation as largely, if not solely, a matter of science. This is not self-evident. In 1913, when Sarasin organized his Internationale Weltnaturschutzkonferenz, this was still a relatively new idea. When in 1900, a meeting had been held in London to discuss a convention for the preservation of African wildlife, the small committee, after all, had consisted mostly of diplomats, big game hunters and colonial officers. Only one naturalist had been present. ${ }^{54}$ Nine years later, at the International Conference for the

\footnotetext{
${ }^{51}$ Norman Myers et al. "Biodiversity Hotspots for Conservation Priorities," Nature 403 (2000), 853-859.

${ }^{52}$ See e.g. National Parks, Conservation and Development, 667-671.

${ }^{53}$ Stevens notably referred to the UN Conference on Environment and Development (in Rio) and the Fourth World Congress on National Parks and Protected Areas (in Caracas), both held in 1992. Stan Stevens, "New Alliances for Conservation," in Conservation through Cultural Survival: Indigenous People and Protected Areas, Stan Stevens ed. (Washington D.C.: Island Press, 1997) 43.

${ }_{54}$ Mark Cioc, The Game of Conservation: International Treaties to Protect the World's Migratory Animals (Athens: Ohio, Ohio University Press, 2009), 34-40; Gissibl, The Nature.
} 
Protection of Landscapes in Paris, it was particularly artists, politicians and lawyers that were represented. ${ }^{55}$ Conservation, it might be clear, could have different types of spokespersons.

With Sarasin's conference, scientific experts clearly took the stage. Naturalists, mostly zoologists and botanists, made up the biggest group of participants in Bern (38\%), now clearly outnumbering the lawyers and diplomats (together 26\%). Applied scientists, notably with a background in forestry, added to the scientific outlook of the meeting. This tendency of 'scientification' was further confirmed in the interwar years. Natural history became the key discipline, always providing between a quarter and the half of the participants to the conferences. Natural history museums often served as host institutions of the conferences or as destinations of conference excursions. Next to (museum) naturalists, also agricultural engineers, state foresters and game wardens were present in important numbers. Yet, the scientification was neither immediate nor complete. The Paris conference of 1923, for instance, still largely drew on a local Parisian lay audience. Several participants are for example listed as merchants $(7 \%)$, teachers $(3 \%)$ or industrialists $(2 \%)$. In the following decades those categories would gradually disappear.

After World War II, biologists continued to make up the core group of most expertbased conservation conferences. Old style naturalism, however, would gradually be replaced by new disciplines. The 1940s, for example, saw the rise of scientific ecology. At the Lake Success conference (1949) ecologists participated for the first time in substantial numbers constituting $10 \%$ of the attendants. It was also in this period that leading voices in both conservation organizations and universities started to stress the complementary relationship between ecological research and conservation practice. ${ }^{56}$ The French zoologist George Petit seemed to voice a widespread idea among the attendants at Lake Success when he claimed that

\footnotetext{
${ }^{55}$ Raoul de Clermont et al. (eds), Le $1^{\text {er }}$ congrès international pour la protection des paysages. Compte rendu (Paris : Société pour la protection des paysages de France, 1910).

${ }^{56}$ Wöbse, "The World After All was One," 331-348.
} 
'with ecology conservation found its scientific foundation. ${ }^{, 57}$ Not much later IUPN would set up a Commission for Ecology and hire its first staff ecologist (in 1954). ${ }^{58}$ Yet, the strong sense of anticipation surrounding the term 'ecology' around 1950 was not really reflected in the participant lists of conferences of later decades. This might partially be explained by the intricacies of academic terminology and the relativity of disciplinary boundaries. Some people listed as 'zoologist', for example, actually performed ecological research. Overall, it is clear that professional positions in ecology remained rarities (particularly outside the AngloAmerican world).

Contemporaneously with the ecologists, also wildlife managers entered the conference circuit. Wildlife Management originated in the United States of the 1930s - with Aldo Leopold's Game Management being published in 1933 and The Journal of Wildlife Management being founded in 1937. In the postwar period the discipline was increasingly incorporated in the administration of European colonies. ${ }^{59}$ The first wildlife managers appeared on the participant lists of international conferences in the late 1940s (with $4 \%$ of the participants at Lake Success). The term 'wildlife manager' was for a while used alongside 'game warden', but often both expressions were used interchangeably. Self-evidently the two categories were particularly well-represented at conferences devoted to national parks. ${ }^{60}$

Terms such as 'naturalist', 'ecologist' and 'wildlife manager' were linked to institutional settings (respectively museums, universities and national parks) rather than to wellbordered disciplines. In the period under discussion it is clear that the three types of experts largely agreed that the object of protection should be 'unspoiled' nature, that the biological sciences were to inform its rationale, and that parks and reserves must be its main instruments.

\footnotetext{
${ }^{57}$ International Technical Conference, 314.

${ }^{58}$ Holdgate, The Green Web, 62-71.

${ }^{59}$ Neumann, "The Postwar Conservation Boom," 33-35.

${ }^{60}$ They made up 15\%, 27\% and 10\% of the attendants in respectively Bukavu (1953), Seattle (1962) and Yellowstone (1972).
} 
Yet, because of the aforementioned developments of the 1970s - the rise of an environmental policy field and an increasing role for the UN in conservation matters - these ideas were challenged by new types of experts. Among others, economists entered the conservation scene. Notably in the wake of UNCHE in 1972, experts started to discuss conservation issues increasingly in the light of economic development. It was notably leading circles in the UN around Maurice Strong that pushed this agenda. Through the concept of 'sustainable development' economists found a niche as development experts at conservation conferences. ${ }^{61}$ Particularly UNEP, the new organization established at the Stockholm Conference, invited economists to its meetings. At the UNEP-organized conference at Cocoyoc (1974), for instance, economists formed the majority (42\%) of the participants.

Contemporaneously with the economists, environmental lawyers became increasingly prominent. Environmental law had always been an important aspect at conservation conferences, but as a discipline it went through a phase of institutionalization only in the 1970s. A series of conventions following UNCHE (such as the Ramsar and Bonn convention) created institutions that had to secure the legal follow-up of the decisions taken. The International Council of Environmental Law set up in New Delhi (1969), and the Environmental Law Center created by IUCN (1970) also provided an important input. ${ }^{62}$ It is these institutions that delivered the leading voices of environmental law at international conferences - among them Wolfgang Burhenne, Françoise Burhenne-Guilmin and Cyrille de Klemm. They represented a growing contingent of professionals. At the conferences of New York (1971), Bonn (1976) and Geneva (1988-1990) environmental lawyers made up respectively $12 \%, 14 \%$ and $21 \%$ of the participants.

\footnotetext{
${ }^{61}$ Nico Schrijver, Development without Destruction: The UN and Global resource Management (Bloomington, Indiana, Indiana University Press, 2010) 48-50.

${ }^{62}$ See: Barbara J. Lausche, Weaving a Web of Environmental Law: Contributions of the IUCN Environmental Programme (Bonn: Schmidt Erich Verlag, 2008).
} 
The economists and lawyers were, furthermore, joined by a diverse group of specialists including educationalists, social scientists and spatial planners. That the conservation community actively sought the advice of such experts was indicative of a change in approach. From the 1970s onward, the conservation agenda increasingly broadened to natural resources and development, and the idea gained ground that managing nature also involved managing humans. ${ }^{63}$ Occasionally, such experts from outside the traditional preservation network used conferences to actively reframe conservation. Former business man Strong and economist Barbara Ward, for instance, utilized the Cocoyoc conference to highlight that the environmental problem was about 'economic and social maldistribution', while spatial planner Peter Jacobs organized the Ottowa conference to wed conservation to equity issues. ${ }^{64}$ Yet, despite such interventions, the new experts hardly managed to conquer a permanent place in the heart of the international conservation network. Until well into the 1980s, the biological scientists continued to dominate much of the conferences, both in terms of numbers and setting the agenda. ${ }^{65}$ Unspoiled nature, protected by law, set apart in protected areas, and scientifically managed by biologists, remained the main object of attention.

\section{Gendered Conference Culture}

The diversity of the network of conservationists can not only be measured in terms of its national or disciplinary composition, but also by looking at its gender balance. This is important if we want to understand the self-fashioning of the conservation expert. Expert roles, after all, are often highly gendered, and the forms they take are partially related to the relative inclusion

\footnotetext{
${ }^{63}$ Amongst others: Boardman, International Organization, 68-72; Holdgate, The Green Web, 100-129.

64 “The Declaration of Cocoyoc," World Devlopment, vol 3, 2 (1975), 141, ; Peter Jacobs, Julia Gardner and David Munro, "Sustainable and Equitable Development: An Emerging Paradigm," in: Jacobs and Munro (eds.), Conservation with Equity, 17-29..

${ }^{65}$ In Bali (1982), Minsk (1983), Ottawa (1986) and Geneva (1988-1991) the biological scientists always provided the biggest contingent with respectively $53 \%, 47 \%, 26 \%$ and $31 \%$ of the participants.
} 
of women in the network. ${ }^{66}$ This inclusion was very limited for most of the period studied. If we exclude traveling partners (who are not always registered on the participant lists), there is only a substantial increase of female participation in the 1980s. On the total of the participants listed for the 21 conferences, only $8 \%$ are women. When we look at those numbers in more detail it becomes clear that women were notably absent at the smaller, more exclusive meetings that prepared conventions. At the conferences of Bern (1913), London (1933 and 1938) and Ramsar (1970) there were even no women present whatsoever.

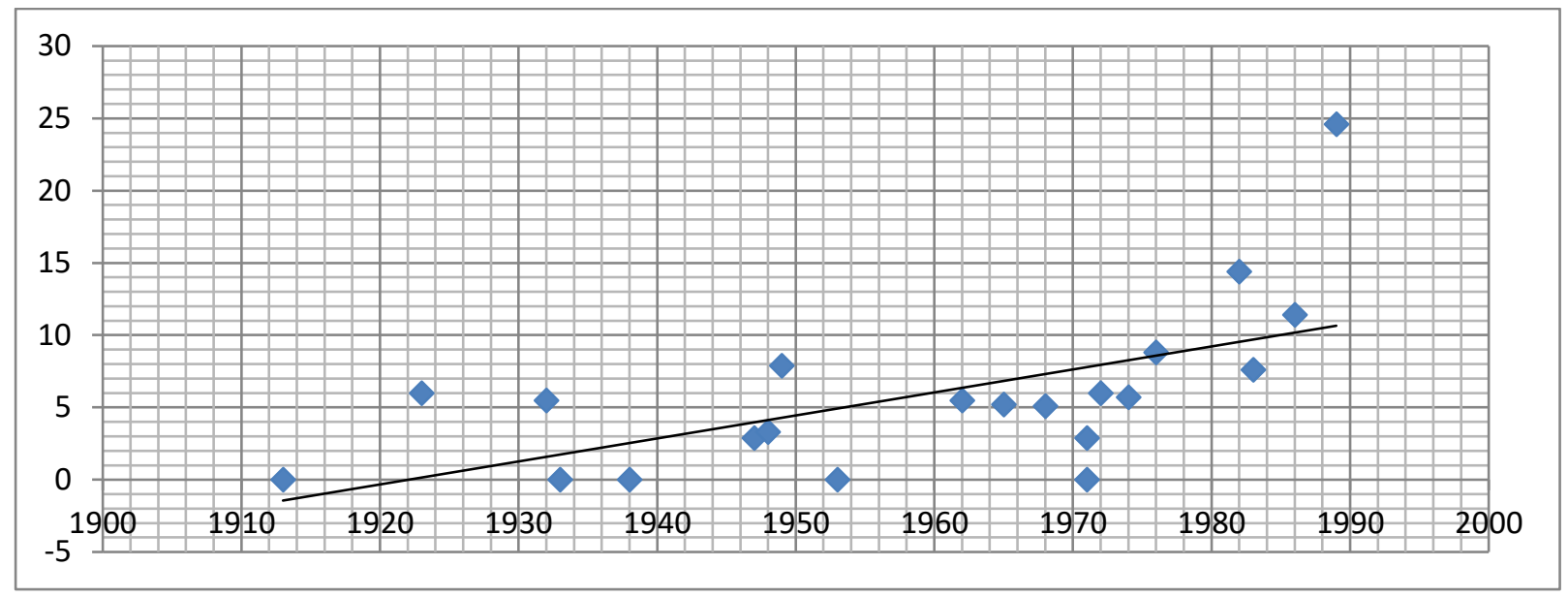

Percentage of female representatives at international conservation conferences

We should not, however, assume that women were completely excluded from the conservation network in the early and mid-twentieth century. To begin with there are some notable exceptions. One of the regulars at the early conferences was, for instance, Marquise de Pierre, the founder of the Royal Belgian League for the Protection of Birds. And at mid-century the British-Chinese Eleen Sam, Program Specialist at the Natural Sciences Sector of UNESCO, took up a central role. Both, however, were active in fields that were considered feminine. The bird protection movement, in which Marquise de Pierre was active, originated from female organizations that countered the fashion of feathered hats. ${ }^{67}$ Within the conservation movement

\footnotetext{
${ }^{66}$ This argument has been made with regard to the field sciences (which, obviously, were crucial to conservation) in: Henrika Kucklick and Robert E. Kohler, "Introduction," Osiris, vol 11: Science in the Field (1996), 12-13.

${ }^{67}$ See: Robin W. Doughty, Feather Fashions and Bird Preservation: A Study in Nature Protection (Berkeley: University of California Press, 1975).
} 
at large this tradition was often denounced as 'sentimentalist', and of Marquise de Pierre the talk in the corridors was that 'only with some reserve she could be taken serious'. ${ }^{68}$ Sam to the contrary did have an aura of seriousness, but also she took up a female role. She was, after all, sought after for her organizing skills and her inside knowledge of UN bureaucracy - not for particular scientific knowledge. ${ }^{69}$

Apart from these few visible female conference participants, it is clear that women did important behind-the-scene work that was not always discernible at the front stage that conferences constitute. Secretaries of many early conservation institutions were women: Tordis Graim at the IOPN, Phyllis Barclay-Smith at the International Committee for the Protection of Birds (ICPB), Marguerite Caram at IUPN. In their role as secretary they often took an active part in the preparation of conferences and the construction of the international network. ${ }^{70}$ Again, their role was not usually seen as expert-related, and despite their organizing function they did not necessarily attend the conferences themselves. Only exceptionally did they take up more of a front stage role, and when they did - as for instance Barclay-Smith would - this was not always appreciated. Graim, for instance, believed Barclay-Smith's ambitions to constitute a form of 'misguided feminism'. ${ }^{71}$

The underrepresentation of women in the conservation movement eventually became an issue in conservation circles in the 1970s, and it lasted another decade for gender equity programs to pay off. Significant in that respect was - also here - the UN engagement with the topic. From 1975 onward the organization set up its Conferences on Women, which also found

\footnotetext{
${ }^{68}$ Tienhoven to Miss Derscheid, 20 May 1927 and to Jean-Marie Derscheid 23 June 1927, Tienhoven Papers, ACA, 1283-55.

${ }^{69}$ IUPN Secretary-general Harroy for instance often sought her insider's advice, because with regard to UNESCO he often felt like 'a schoolboy facing an impressing examination board'. Harroy to Sam, 9 January 1951, UNESCO Archives, 502.7 A 01 IUCNNR -6.

${ }^{70}$ With the exception of Barclay-Smith these women, significantly, hardly left a trace in biographical reference works. Their important role, however, stands out very clearly in the correspondence of international conservation leaders. See e.g. Tienhoven papers (ACA, 1283-64-66) and the UNESCO archives (502.7 A 01 IUCNNR -6). About Barclay-Smith: Colin J.O. Harrison, 'Smith (Ida) Phyllis Barclay', Oxford Dictionary of National Biography, 51 267-268.

${ }^{71}$ Graim to Tienhoven, July 6, 1936, Tienhoven Papers, ACA, 1283-65.
} 
their echo among the conservation community. The IUCN General Assembly of 1984 issued a women's petition to promote 'the involvement of women in IUCN, particularly with regard to "key positions", and at the Ottawa conference of 1986 a similar standpoint made it into a conference recommendation. ${ }^{72}$ The fact that the newly founded World Commission on Environment and Development had Gro Harlem Brundtland as a chair gave further momentum to the equity movement. ${ }^{73}$

In this period not only the number of women, but also their role in the conference network changed. Increasingly, women in the network took up roles that were traditionally male. Brundtlandt was neither a 'sentimental' bird protector nor a secretary with organizational tasks. As a scientist and former prime minister of Norway, she was a public figure with an aura of both expertise and power. Other women of the same generation entered the conference circuit and further diversified the group. The Belgian environmental lawyer Françoise BurhenneGuilmin, for instance, played a prominent role in legal negotiations, whereas the Tunisian geneticist Hedia Baccar significantly contributed to international debates on the protection of the Mediterranean. ${ }^{74}$ In the database in general, the group of women in the period after 1970 is diverse and consists of $18 \%$ biological experts, $12 \%$ lawyers and $9 \%$ diplomats. This being said, it is important to stress the continued female underrepresentation in the total numbers of participants up until the end of the period studied.

\section{A Congress Elite}

\footnotetext{
${ }^{72}$ 16th Session of the General Assembly: Madrid, Spain, 6-14 November 1984: Proceedings (Gland: IUCN, 1984) 165; Peter Jacobs and David Munro, "Conservation with Equity: Strategies for Sustainable Development," Proceedings of the Conference on Conservation and Development, 451.

${ }^{73}$ Pietronella van den Oever - who was closely involved in the equity movement within international conservation - explicitly referred to the appointment of Brundtland as a 'game change' (Email message to author March 17, 2014).

${ }^{74}$ See respectively: Nicholan Polunin ed., World Who is Who and does What in Environment \& Conservation (London: Earthscan, 1996) 42: Lausche, Weaving a Web, 42-43; https://www.linkedin.com/pub/hediabaccar/28/6/600.
} 
Of course, not everyone present at an international conference necessarily was an influential player in the global conservation network. A great majority of the participants (almost $80 \%$ ) only appear in the database once. When looking at the group that returns regularly at conferences (4 times or more), only a small group remains. We look at this elite - which makes up less than a percent of the total of conference participants - in some more detail.

\begin{tabular}{|c|c|c|c|c|}
\hline $\mathrm{N}^{\circ}$ & Name & Conferences & Country & \\
\hline 1. & Harold Coolidge & 1948-1949-1962-1965-1968-1972-1982 & US & 7 \\
\hline 2. & Jean-Paul Harroy & 1948-1949-1953-1962-1965-1968-1972 & $\mathrm{BE}$ & 7 \\
\hline 3. & Walery Goetel & 1923-1932-1947-1948-1962-1971a & PL & 6 \\
\hline 4. & Pieter Gerbrand van Tienhoven & 1923-1932-1933-1938-1947-1948 & NL & 6 \\
\hline 5. & Michel Batisse & 1968-1971a-1972-1982-1983 & FR & 5 \\
\hline 6. & Gerardo Budowski & 1962-1968-1972-1982-1988 & VE & 5 \\
\hline 7. & Keith Caldwell & 1932-1933-1938-1948-1953 & UK & 5 \\
\hline 8. & Frank Fraser Darling & 1948-1949-1965-1968-1971a & UK & 5 \\
\hline 9. & Ray Dasmann & 1968-1972-1982-1983-1986 & US & 5 \\
\hline 10. & Hugh Elliott & 1965-1968-1971-1972-1976 & $\mathrm{UK}$ & 5 \\
\hline 11. & Frank G. Nicholls & 1965-1971a-1971b-1972-1976 & $\mathrm{AU}$ & 5 \\
\hline 12. & Lee Talbot & 1962-1965-1968-1971a-1982 & US & 5 \\
\hline 13. & François Bourlière & 1962-1965-1968-1971a & FR & 4 \\
\hline 14. & Wolfgang Burhenne & 1968-1982-1986-1988 & $\mathrm{DE}$ & 4 \\
\hline 15. & Kai Curry-Lindahl & 1962-1968-1972-1976 & SE & 4 \\
\hline 16. & Jean Delacour & 1923-1932-1947-1949 & FR & 4 \\
\hline 17. & Bernd von Droste & 1982-1983-1986-1988 & $\mathrm{DE}$ & 4 \\
\hline 18. & Johannes Goudswaard & 1947-1948-1965-1968 & $\mathrm{NL}$ & 4 \\
\hline 19. & Clinton Raymond Gutermuth & 1949-1962-1972-1982 & US & 4 \\
\hline 20. & Luc Hofmann & 1968-1972-1982-1986 & $\mathrm{CH}$ & 4 \\
\hline 21. & Shri N.D. Jayal & 1976-1982-1983-1986 & IN & 4 \\
\hline 22. & Cyrille de Klemm & 1968-1976-1982-1986 & FR & 4 \\
\hline 23. & Wim G. van der Kloot & 1947-1948-1962-1972 & NL & 4 \\
\hline 24. & Walter J. Lusigi & 1976-1971a-1971-1986 & $\mathrm{KE}$ & 4 \\
\hline 25. & Jeffrey McNeely & 1982-1983-1986-1988 & US & 4 \\
\hline 26. & Kenton R. Miller & 1972-1982-1983-1986 & US & 4 \\
\hline 27. & Daniel B. Navid & 1971-1982-1986-1988 & US & 4 \\
\hline 28. & Théodore Monod & 1932-1949-1962-1968 & FR & 4 \\
\hline 29. & Duncan Poore & 1970b-1972-1976-1983 & UK & 4 \\
\hline 30. & Carleton Ray & 1962-1972-1982-1986 & US & 4 \\
\hline 31. & George Frederick Herbert Smith & 1932-1933-1947-1948 & UK & 4 \\
\hline 32. & Victor van Straelen & 1933-1938-1948-1962 & $\mathrm{BE}$ & 4 \\
\hline
\end{tabular}


The biographical data of the members of the congress elite - combined with the proceedings of the conferences in question - show that they were more than just attendants. ${ }^{75}$ Most of them were highly visible at the conferences as keynote speakers and session chairs. Furthermore, they also saw each other in committee and board meetings that were often held in the margin of bigger conferences. Alongside meeting in the context of conferences, they strengthened their ties through private correspondence and personal visits. ${ }^{76}$ Most of them took up formal leadership in various conservation organizations, and authored or co-authored key documents of these organizations. Although not always cordial, the contacts within this small group were overall very tight.

When looking at its composition, the list of conference regulars confirms the major tendencies we observed for the group of attendants as a whole. In fact the tendencies are even more outspoken. The list does not include a single woman. The great majority of the congress elite, furthermore, originates from western countries with a particular role for the United States, France and the United Kingdom. The only 'non-westerners' (Budowski, Jayal and Lusigi) enter the network in the 1960s and 1970s, and come from places we identified as local centers in the global network (Venezuela, India and Kenya). Disciplinarily, the group's make-up is diverse,

\footnotetext{
${ }^{75}$ Biographical data of the conference elite can be found scattered over biographical dictionaries, memoirs and obituaries. Many of the late twentieth century personalities can be found in: Polunin ed., World Who is Who. Further, we used, amongst others: Dasmann, Called by the Wild; Jean Delacour, The Living Air: The Memoirs of an Ornithologist (London: Country Life Limited, 1966); "Dr. G.F. Herbert Smith," Nature, 139 (1937), 873; Richard Fitter, "Sir Hugh Elliott (1913-1989)," Ibis, 132 (1990), 222-224; Hoffmann and Silberstein, Luc Hoffmann; Kenneth Mellanby, "Darling, Sir Frank Moss Fraser," Oxford Dictionary of National Biography, vol. 15 (2004), 149; Elio Pelzers, "Tienhoven, Pieter Gerbrand van (1875-1953)," Biografisch woordenboek van Nederland, vol. 4 (1994), 495-497; Lee Talbot, "Dedication to Dr Harold Coolidge," Environmentalist, 2 (1982), 281-282; François Stockmans, "Notice sur Victor van Straelen," Annuaire de l'Académie Royale de Belgique, (1973) 1-90; Edward Steinhart, Black Poachers, White Hunters: A Social History of Hunting in Colonial Kenya (Athens, Ohio: Ohio University Press, 2006), 155-158; Gustav A. Swanson, "Kai Curry-Lindahl (1917-1990)," Wildlife Society Bulletin, 19 (1991), 556-558; Jean-Jacques Symoens, "Harroy, Jean-Paul," Nouvelle Biographie Nationale, vol. 5 (2001), 237-241; Henny van der Windt, En dan: Wat is natuur nog in dit land? Natuurbescherming in Nederland, 1880-1990 (Amsterdam/Meppel: Boom, 1995), 105-118; François Vueilleumier, "In memoriam François Bourlière," The Auk, 111 (1994), 993-995; "Walery Goetel (1889-1972)," Rocznik Polskiego Towarzystwa Geologicznego, 43 (1973), 555-568.

${ }^{76}$ Alongside institutional archives, also personal archives - such as the Michel Batisse papers (UNESCO Archies, Paris) Harold Coolidge Papers (Harvard University Archives), Tienhoven Papers (City Archive, Amsterdam) show how closely the members listed here were in touch.
} 
but biologists are clearly dominant. Over time the composition of the congress elite - like that of overall participants - shows a shift from naturalists to ecologists at mid-century, while environmental lawyers enter from the late 1960s onward.

When looking closer at the biographies of the elite members we see that their training, disciplinary allegiance and trajectories were diverse and often little straightforward. To be sure, most of them received higher education at a limited number of western universities, and two thirds acquired a $\mathrm{PhD}$, but the group as a whole never clustered around one particular discipline. Even for single individuals it is often difficult to link them to one particular scientific field. Some could clearly be identified as zoologists (Curry-Lindahl, Ray and Coolidge), botanists (Poore) or wildlife managers (Caldwell), but most had mixed or shifting disciplinary identities. François Bourlière was a gerontologist and amateur ornithologist, McNeely an anthropologistturned-zoologist, and Frank Nicholls and Michel Batisse were physicists making careers as administrators. Frank Fraser Darling was an agriculturalist-turned-geneticist-turned-ecologist and Johannes Goudswaard an engineer who became an expert in environmental education. Théodore Monod was a zoologist as well as a philosopher. Harroy, finally, was trained as a commercial engineer, and subsequently acted as park administrator, IUPN secretary-general and governor of Ruanda-Urundi. What these men shared, it seems, was the ability to act in multiple roles.

Despite a continued disciplinary and professional diversity, one does see a professionalization in the conservation elite over time. Before 1945 nature protection was a voluntary side project even for its international leaders. Typically it was taken up by museum curators (such as Van Straelen, Smith or Goetel), but also by people of wealth with an interest in ornithology or collecting. The most influential person in the network during the interwar years, Pieter Gerbrand van Tienhoven, was the owner of an insurance agency, while Jean Delacour was a well-to-do gentleman scientist. After the Second World War, one sees a 
growing influence of people who were employed by international organizations (such as Batisse, Harroy or Talbot), or who worked as state administrators (Van der Kloot, Jayal, Elliott). Nonetheless, conservationists often still relied on an improvised combination of different types of funding, and the odd gentleman scientist remained. Luc Hoffmann, shareholder of Hoffmann-Laroche chemicals and co-founder of the World Wildlife Fund (WWF), offers a case in point.

In terms of institutional affiliation, the elite covered a broad field. Before the war, the Brussels-based IOPN was important, alongside the British SPFE. After 1948, the institutional backbone of the network clearly becomes the semi-governmental IUCN to which no less than 25 individuals of the elite were (temporarily) affiliated. Another important role was played by IUCN's main funders: on the one hand the UN special agency UNESCO, on the other hand the non-governmental WWF. But the involvement of the elite ranged wider. Many of its members were also involved in IUCN's 'sister organization' the ICPB, took part in projects of UNEP, or were associated to the International Biological Program (1964-1974) - which had been designed to turn ecology into a 'big science'. The tentacles of the network ranged to the Food and Agriculture Organization (FAO), the Council of Europe and the World Bank.

While some individuals of the elite built an entire career within one institution, most took subsequent jobs at universities, international organizations and governmental agencies. Often they would combine several affiliations at the same time. The career of Lee Talbot offers a good example. After studying wildlife conservation at Berkeley, he became IUCN's first staff ecologist in 1953. In the following decade he performed fieldwork in Africa and Asia employed by the IUCN, the National Academy of Sciences and the UN. In the late 1960s he returned to the United States to work for the Smithsonian Institution and, later, for the President's Council on Environmental Quality. In the late 1970s he served as conservation director of the WWF and between 1980 and 1983 as the director-general of IUCN. He ended 
his career in academia, while also acting as a consultant for the World Bank, FAO and UNESCO. ${ }^{77}$ For careers like Talbot's, relations within the network of the congress elite were crucial. Harold Coolidge's support, for instance, was vital - from finding money for hiring IUCN's staff ecologist in the 1950s to pushing Talbot's candidacy as director-general of the same organization in the 1980s. ${ }^{78}$ This was by no means exceptional. The examples of such internal support within the congress elite could be endlessly extended. ${ }^{79}$

The elite's multiplicity of engagements did not just concern international organizations and scientific institutions. Next to global policy, many of them were involved in highly localized activism concerning particular landscapes or ecosystems. Through their position at the local-global nexus they were able to bring these places to international attention. On the one hand this enabled them to mobilize international pressure to preserve the local nature they valued (the so-called 'boomerang pattern') ${ }^{80}$ In the other direction it allowed them to promote local successes as models to be copied elsewhere. A good example of the first process is offered by Walery Goetel's activities in the Polish Tatra Association. When in the 1930s plans were made to create a railroad in the Tatra National Park, fellow members of the congress elite were called up to protest. Amongst others, Van Tienhoven and Van Straelen published alarming articles in their national newspapers. ${ }^{81}$ An example of the second route is Hoffmann's flagging of the Camargue region as an international model of scientific wetland protection. When, in 1962, he set up the so-called MAR-conference on wetland conservation, he made sure to have

\footnotetext{
77 Interview with Talbot by the Author, 11 and 15 September 2014. For a full cv of Talbot: http://mason.gmu.edu/ ltalbot/talbotcv.html

${ }^{78}$ Holdgate, The Green Web, 62 and 163.

${ }^{79}$ The examples of such internal support within the congress elite can be endlessly extended. Van Straelen, for instance, piloted his compatriot and colleague Harroy into the network. Dasmann, then, was introduced in IUCN by Budowksi; Both knew each other from their time at UNESCO, to which they were attracted by Batisse.

${ }^{80}$ Margaret E. Keck and Kathryn Sikkink, Activists beyond Borders: Advocacy Networks in International Politics (Ithaca 1998) 12.

${ }^{81}$ Tienhoven to Tordis Graim, 5 November 1935, Tienhoven Papers, ACA, 1283-65.
} 
it take place in the Camargue area itself, and to combine scientific papers with excursions to the nature reserve and his own biological station. ${ }^{82}$

The local connection not only concerned an attachment to particular landscapes, but also a personal link to home-grown networks. Many figures of the elite were characterized by what social network scholars have called 'high levels of betweenness'. 'Betweenness' refers to 'the degree to which a given individual connects other members of the network who are otherwise disconnected'. ${ }^{83}$ Van Tienhoven is a good example. In the interwar years he accumulated leading positions in various Dutch conservation organizations such as the Dutch Society for the Protection of Birds and Natuurmonumenten, and he acted as a liaison between these organizations and the international elite. Next to enabling this 'vertical' connection between the national and the international level, Van Tienhoven also strengthened 'horizontal' connections at the international level itself. In the interwar years, he was the only person who was a member of the three international conservation organizations based in Europe: the IOPN, the ICPB and the International Society for the Protection of the European Bison. ${ }^{84}$ All this made him an important gatekeeper of information. The same is true for most other members of the congress elite. Men such as Burhenne, Dasmann and Talbot all combined multiple organizational functions at various local, national and international societies.

Local connections were clearly important for the global network, but these did not necessarily involve the conservationists' home countries. The congress elite were characterized by their geographical mobility. Particularly striking in this regard is their orientation to the tropics. Two thirds of the congress elite spent substantial time in tropical regions - either in a

\footnotetext{
82 'Conference Chronicle', Project MAR: The Conservation and Management of Temperate Marshes, Bogs and Other Wetlands (Morges: IUCN, 1964), 24-25.

${ }^{83}$ Hagald Katz and Helmut Anheier, "Global Connectedness: The Structure of Transnational NGO Networks," Global Civil Society 2005/6 (London: SAGE, 2006), 254.

${ }^{84}$ See amongst others: Elio Pelzers, E. Geschiedenis van de Nederlandse commissie voor internationale natuurberscherming, de Stichting tot internationale natuurbescherming en het Office international pour la protection de la nature (Amsterdam: Nederlandse commissie voor internationale natuurbescherming, 1994).
} 
long-term scientific function on the ground or as participant in expeditions. Typical destinations were the savannahs of Eastern Africa, the Albert National Park (currently Virunga National Park) in Belgian Congo, and the rainforests of South-East Asia and Latin America. ${ }^{85}$ Excursions to such places - which return throughout the entire period studied - fulfilled various functions. They served as rites of passage, constituted instances of network-building, and played an important role in creating a common idea of what valuable nature was and where it was situated. ${ }^{86}$

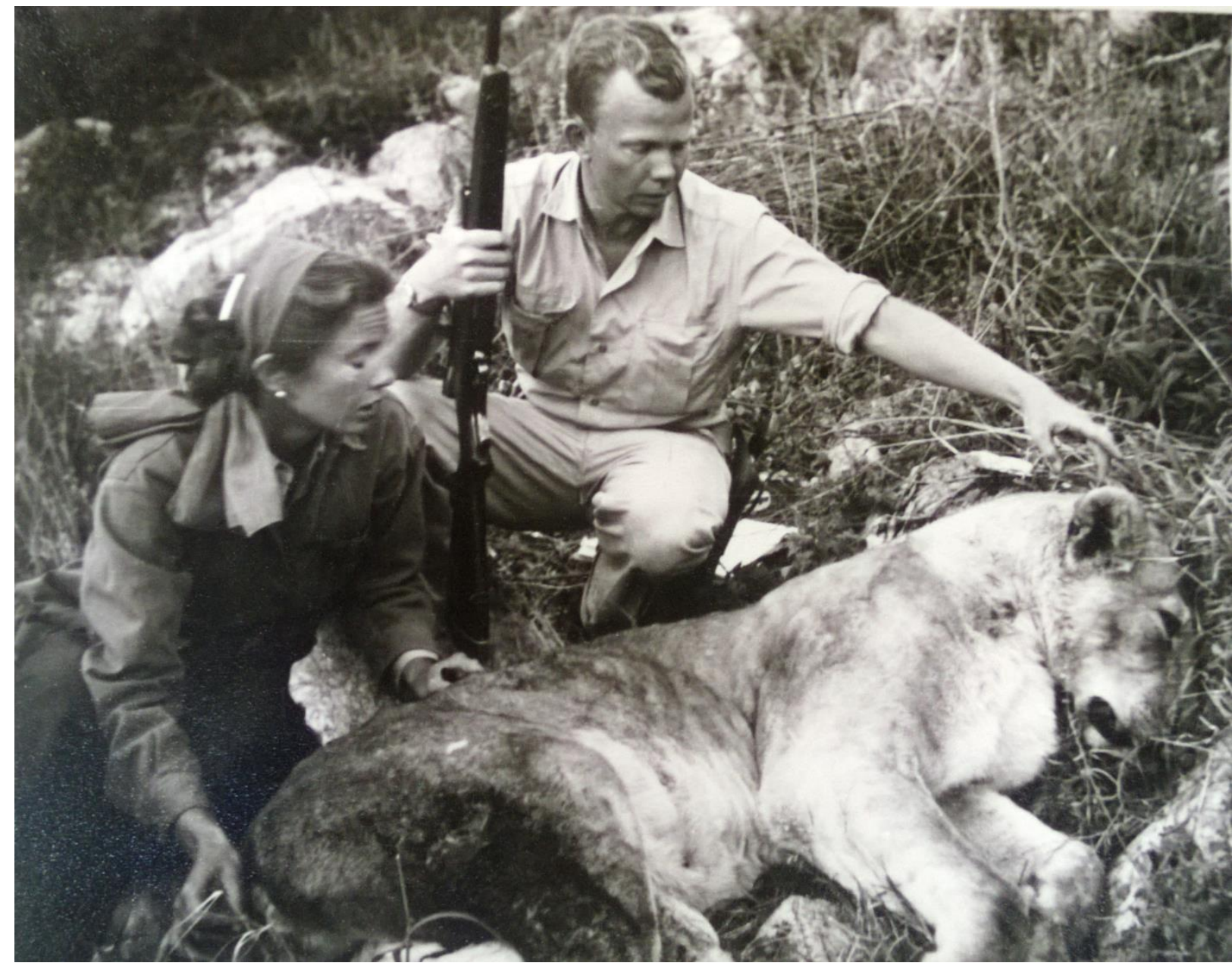

The bigger part of the conference elite went on field experience in the tropics. On the picture: Martie and Lee Talbot raiding a lioness, Kenya, 1960 (Harvard College Archives, Coolidge Papers, HUG (FP) 78.75).

\footnotetext{
${ }^{85}$ On the basis of the biographical data 24 members of the 'elite' were engaged in expeditions of fieldwork of some sort. We counted 7 people with field experience in East-Africa, 6 in Belgian Congo or Zaire, 6 in SouthEast-Asia, and 5 in South- and Central-America.

${ }^{86}$ Compare: Rachelle Adam, Elephant Treaties: The Colonial Legacy of the Biodiversity Crisis (Lebanon, New Hamshire: UPNE, 2014).
} 
The position of the elite, however, was never uncontested. This became, for instance, eminently clear during the drafting process of the World Conservation Strategy in the late 1970s. This common document of IUCN, UNEP, UNESCO and WWF took much of the energy of the international conservation community in that period, and was a source of discussion both at public conferences and behind the scenes. Early drafts of the Strategy drew heavily on the ideas of the IUCN luminaries that dominated the congress elite of those years (such as Poore and Dasmann). ${ }^{87}$ WWF-commentators, however, believed these drafts gave up too many wildlife concerns to accommodate development goals in the Third World. ${ }^{88}$ Within UNEP circles, then, exactly the opposite was argued. External consultants hired by UNEP stressed the drafted documents carried the mark of an 'old boy network' and did not pay enough attention to economic issues in the Global South. They indicated that IUCN experts might have carried out naturalist expeditions to the tropics, but lacked real experience in working with local people in developing countries. ${ }^{89}$ Eventually it took numerous rewrites, pendulum diplomacy, as well as some deliberate conceptual vagueness to cover the differences of opinion. This shows that, while the congress elite played a connecting role within international conservation, its power had its limits. In the Strategy as in other projects, the elite became confronted with diverging conservation philosophies, disciplinary allegiances, and institutional identities.

The significance of the congress elite, we would argue, lay in its power to draw particular places, institutions and disciplines into the endeavor of global conservation. The

\footnotetext{
${ }^{87}$ Poore was engaged in the drafting process itself. Dasmann had left IUCN to take up a position at the University of California, Santa Cruz, but the ideas he developed in the mid-1970s still loomed large in early drafts. Raymond Dasmann, 'Ecological Principles and their Application to Development Planning', in: Papers and Proceedings of the Twelfth Technical Meeting, Banff, Canada, 12-15 September 1972 (Morges: IUCN, 1973) 131-143; IUCN, First Draft of a World Conservation Strategy (January 1978), The Linnean Society of London: Gren Lucas Papers; Holdgate, The Green Web, 149-155.

${ }^{88}$ Thomas Lovejoy to Robert Allen, June 1, 1978, quoted in Stephen J. Macekura, Of Limits and Growth: The Rise of Global Sustainable Development in the Twentieth Century (Cambridge: Cambridge University Press, 2015) 241.

${ }^{89}$ Thomas F. Power and Jorge Morello, "Evaluation of Projects Contracted for Execution to IUCN as a Supporting Organization (11 May 1979)," Harvard College, Environmental Science and Public Policy Archives: Peter S. Thacher Papers, Box 58, Folder 555, pp. 25-28.
} 
frictions at the network's boundaries indicate that a lot was at stake. The elite's composition and connections to an important degree determined which projects were included, and - equally important - which were not. Throughout the twentieth century it was a conscious and partially strategic choice of the conservation elite to expand the network to include more non-western researchers, non-biologists and women. At the same time, the same elite often confirmed traditional approaches and constrained reform. Despite being challenged, their focus largely remained uninhabited nature, the core expertise continued to be sought in the biological sciences, while the key instruments of conservation were still seen to be national parks and international conventions on species. In the early 1980s, Kenton Miller kept pushing these focal points with the slogan 'parks for sustainable development', while a decade later Jeffrey McNeely had a similar goal when he borrowed the concept 'biodiversity' from the conservation biologists. ${ }^{90}$ With such new terminology men like Miller and McNeely showed themselves cognizant of the sensibilities of the time, but they largely employed the new language to keep traditional concerns alive.

\section{Conclusion}

When addressing the participants of the Lake Success Conference in 1949, Harroy typified his audience as a 'vanguard of enthusiasts throughout the world, who often seem to be preaching in the desert'. ${ }^{91}$ Conferences like the one in Lake Success were meant to tie the network of enthusiasts together, and to enhance the impact of their 'preaching'. In this article, we have used such conferences as a means to study the shifting composition of this self-proclaimed global vanguard of conservation.

\footnotetext{
${ }^{90}$ Jeffrey McNeely and Kenton Miller (eds.), National Parks, Conservation and Development: The Role of Protected Areas in Sustaining Society (Washington, DC: Smithsonian Institution Press, 1984); Jeffrey McNeely et al., Conserving the World's Biological Diversity (Gland: IUCN, 1990).

${ }^{91}$ International Technical Conference, XI.
} 
In some aspects the global network fostered by conservation conferences was diverse from the very beginning. Both regarding discipline and institutional affiliation conferences brought together people from different backgrounds. Within the network disciplinary and institutional borders seem to have been weak in general - with at least the congress elite easily crossing them. On the other hand, the network originally showed a strong homogeneity with regard to the nationality and gender of its members. One does see a diversification on both accounts through the twentieth century, but only as the result of a slow and laborious process. Alongside these changes, one also notices the entry of 'new' forms of expertise.

Rather than as a spontaneous development, these forms of diversification can largely be understood as the result of conscious action plans that were often developed from within the network itself. The congress elite acknowledged (or was forced to acknowledge) the need to include new players at several instances. It was particularly from the 1960s onward that the profile of the average conference attendant started to change. This was partially a response to a context of decolonization, the Environmental Revolution and the increasing involvement of the UN in global environmental policy. New players represented forms of expertise such as economic theory or spatial planning, or they represented groups that gained new political meaning - as in the strife for gender balance or the attempts to include participants from the 'developing world'. The inclusion of such groups was partially a strategic response to returning accusations that global conservation was too insular and elitist. In a working document of the mid-1980s, McNeely still found it necessary to stress that international conservationists 'should carefully refute the charge that concern about species is a WASP phenomenon'.92

It is not hard to see that the changes in composition of conference attendants were indeed reflected in the advent of new topics. In the 1940s ecologists started to advocate the protection of biotopes, the 1970s saw an increased attention for development in the Global South, whereas

\footnotetext{
92 Jeffrey McNeely, Discussion Paper; Memorandum from Robert F. Scott to Kenton Miller on 'World Meeting on Species' (20 January 1986), Linnean Society: IUCN Archive.
} 
the role of women in conservation became a returning topic in the $1980 \mathrm{~s} .{ }^{93}$ Yet, this article has also drawn attention to underlying continuities. Although globally oriented, the conservation network sustained a clear center-periphery structure. Geographical centers important during the formation years (notably France and the United Kingdom) maintained an important position during the entire twentieth century - partially because they constituted important loci of institutionalization and discipline-building. Over time new global centers (such as the United States) and regional ones (such as Brazil) arose, and also these would be anchored in institutions and disciplinary structures. Experts from the non-western world that entered the network (such as Lusigi) often strongly resembled their western counterparts. They spoke the same language, were trained in the same sciences (often in the west) and would be socialized in the same conference culture. They belonged to what environmental historian Michael Lewis has described as 'a transnational "comfortable" class' and they perpetuated its values. ${ }^{94}$ Throughout the entire period, conservation work of the majority of conference attendants concerned tropical 'wilderness', a focus that built on colonial structures and interests. Natural history gradually gave way to ecology and wildlife management, but this does not detract from the fact that it was the biological sciences - and more in particular those focused on uninhabited nature - that dominated the ways in which problems were defined and answers were formulated.

Instrumental in this continuity was a core group of conference attendants that was relatively stable. The congress elite brought experts together who were not bound by clearly bordered academic disciplines, and who had careers that were not limited by particular institutions. They played a connecting and stabilizing role and often supported each other's projects over long periods of time. While the elite adapted to new contexts, they defended continuity as it came to conservation's geographical focus, its scientific approach, its

\footnotetext{
${ }^{93}$ See respectively: International Technical Conference, VII; Second World Conference, 90-92; "The Declaration of Cocoyoc," passim.; Conservation with Equity, 412-413.

${ }^{94}$ Lewis, Inventing Global Ecology, 237.
} 
instruments and its key concerns. In the 1980s, McNeely might have expressed his ideas in different terms than Van Tienhoven had in the 1920s, but the core of their ideas was the same. Despite different calls for reform (and actual attempts to reform), the way conservation was conceived in the international conference circuit changed only to a limited extent in the short twentieth century. The small conference elite did establish new and more diverse connections, but it also guarded the contours of an old project. 